\title{
Circulação de saberes e de práticas governativas: caminhos de articulação da política no Brasil, 1845-1860
}

\author{
Maria Luiza Ferreira de Oliveira* \\ Universidade Federal de São Paulo \\ Guarulhos - São Paulo - São Paulo
}

\section{Resuino}

Nesse artigo buscamos mapear circuitos de articulação político administrativa em meados do século XIX no Brasil, pensando em alguns movimentos da construção do Estado que envolviam a circulação de saberes e de práticas governativas. $\mathrm{O}$ texto está dividido em quatro partes. Na primeira, observamos a comunicação entre presidentes de províncias para entender como iam se articulando modos de governar. A circulação de narrativas sobre a administração pública ia conformando um vocabulário, um campo discursivo e um conhecimento compartilhado sobre as diversas províncias. Um dos maiores desafios aos governos do período foram as revoltas, por isso na segunda parte do texto tratamos da relação entre duas províncias, Pernambuco e Alagoas, durante a Guerra do Jacuípe, para esclarecer parte dessa dimensão. Na terceira parte, discutimos outra esfera que envolvia a administração pública, o debate em torno da atuação do governo nas epidemias e nas crises de produção alimentar. Para encerrar o texto, avaliamos a articulação política tecida na correspondência particular, quando fica mais visível a dimensão da luta política e dos interesses materiais. Procuramos também ressaltar, em todos os tópicos, a diversidade de atores políticos em cena, participando das disputas.

\section{Palavras-chave}

modos de governar, articulação política, presidentes provinciais, conservadores.

* Professora de História do Brasil Imperio no Departamento de História da EFLCH - Unifesp, Campus Guarulhos. Possui graduação em História pela Universidade de São Paulo (1993) e doutorado em História Social pela Universidade de São Paulo (2003). Atualmente é professora de história do Brasil no curso de história (Campus Guarulhos) da Universidade Federal de São Paulo, e faz parte do Programa de Pós Graduação da mesma instituição. Contato: mlfoliveira@hotmail.com. 
In this article we seek to map circuits of administrative political articulation in the middle of the nineteenth century in Brazil, thinking of some state - building movements that involved the circulation of knowledge and of government practices. The text is divided into four parts. In the first, we observe the communication between presidents of provinces to understand how they were articulating ways of governing. The circulation of narratives about the public administration was conforming a vocabulary, a discursive field and shared knowledge about the different provinces. One of the greatest challenges to the governments of the period was the revolts, so in the second part of the text we deal with the relationship between two provinces, Pernambuco and Alagoas, during the Jacuípe War, to clarify part of this dimension. In the third part, we discussed another sphere that involved public administration, the debate about government performance in epidemics and food production crises. To close the text, we evaluate the political articulation woven in private correspondence, when the dimension of political struggle and material interests becomes more visible. We also try to emphasize, in all the topics, the diversity of political actors in the scene, participating in the disputes.

\section{Keywords}

modes of governing, political articulation, provincial presidents, conservatives. 
Nesse texto, buscamos mapear circuitos da articulação administrativa em meados do século XIX no Brasil, pensando em alguns movimentos da construção do Estado que envolviam a circulação de saberes e de práticas governativas. No período classificado pela historiografia como da consolidação do Estado - os anos 1850, pouco estava consolidado. Talvez só a escravidão estivesse, pois seguiu robusta e dominante sem o tráfico até os anos 1880. Não conseguiram implementar o Censo, fracassado por conta de uma revolta popular. Havia guerras sendo travadas, províncias pouco conhecidas sendo mapeadas, rios ainda sendo estudados. A regulamentação fundiária não ocorreu. A Guarda Nacional foi timidamente reformada, lentamente. A dimensão do conflito, dos embates, fortemente presentes no período, levou-me a refletir sobre a natureza da construção daquele Estado, privilegiando o entendimento de modus operandi de agentes (administradores, funcionários públicos) e instituições (sobretudo o Exército e os ministérios do Império e da Guerra) em espaços políticos provinciais e nacionais.

$\mathrm{Na}$ correspondência trocada entre os ministros da Guerra e do Império entre 1850 e 1860, lida em sua integridade, questões relativas a todas as províncias do Império apareceram ${ }^{1}$. Tratarei de casos em Mato Grosso, uma província de fronteira, administrada por militares, cheia de desafios para governar e estratégica por seu enquadramento em período de conflitos nos países vizinhos. Um dos temas fortes da década de 1850 era conectar de maneira mais eficiente o Mato Grosso com o resto do Império. Foram estudados rios, encomendadas expedições de mapeamento do território. Analiso também a correspondência dos presidentes de Alagoas e de Pernambuco, duas províncias onde a tensão era forte no período, sendo Pernambuco chave no tabuleiro político do Império. Além disso, tratarei de casos reveladores de práticas administrativas envolvendo a construção de estradas e o controle dos

\footnotetext{
1 O artigo baseia-se em documentação consultada em arquivos estaduais (Mato Grosso, Pernambuco, Alagoas e Minas Gerais - correspondência dos presidentes), no Arquivo Nacional (correspondência dos ministérios da Guerra e do Império), e no IHGB (correspondência particular). Além disso, consultamos jornais e relatórios administrativos.
} 
índios na província de Minas Gerais. O objetivo não é tratar de forma detida a história de cada província, mas pensar em práticas que reverberam e sinalizam para conformações gerais.

A circulação entre as diversas províncias das práticas políticas de cada presidente, de cada assembleia provincial, influenciava na atividade legisladora local e central e provocava o debate público que podia atingir uma repercussão bastante ampla. Um deputado na assembleia de João Pessoa, ou na de Salvador, sabiam das notícias das outras províncias através dos relatórios dos diversos presidentes, das coleções de leis provinciais, dos relatórios ministeriais além dos inúmeros jornais em todas as províncias que costumavam reproduzir trechos dos discursos de deputados, leis, debates nas assembleias, textos de opinião política. Na primeira parte do artigo discutiremos essa circulação, buscando mapear e compreender circuitos em operação no XIX que não se resumiam ao mais conhecido fluxo do centro para as partes. Observar a comunicação entre os presidentes das províncias nos fez entender como o debate ia articulando modos de governar de acordo com determinadas agendas políticas.

Um dos maiores desafios aos governos do período foram as revoltas, as guerras, por isso na segunda parte do texto tratamos da relação entre duas províncias, Pernambuco e Alagoas, durante conflito pouco conhecido, a Guerra do Jacuípe, para esclarecer parte dessa dimensão. Interessou observar como o governo enfrentou, depois de vencida a Farroupilha, em tempos de celebrar a paz, uma guerra nas matas contra um líder popular de grande envergadura, Vicente Ferreira de Paula, em 1845 e 1846. Em seguida discutimos outra esfera fundamental que envolvia a administração pública, o debate em torno da atuação do governo nas epidemias e nas crises de produção alimentar. Fica claro também aí como havia diferentes projetos políticos informando práticas. Para encerrar o texto, avaliamos a articulação política tecida nas redes privadas através dos correligionários políticos nas diversas províncias do país. Na correspondência particular fica mais visível a dimensão da luta política. Mapear a formação de experiências administrativas no XIX implica levar em conta diferentes circuitos, não 
deixando de considerar a disputa política, já que nunca saiu de cena e precisa ser constantemente avaliada.

Um dos momentos que condensava a articulação entre a administração central e provincial era na leitura dos relatórios dos presidentes para o corpo legislativo, na abertura dos trabalhos anuais. Muitas vezes a relação era tensa. José Joaquim de Oliveira explicava em novembro de 1848 ao ministro da Justiça que em seu relatório apresentado à Assembleia majoritariamente da oposição no Mato Grosso tinha omitido muitos fatos sobre a "conspiração política" que encontrou, "para poder conciliar". ${ }^{2}$ Mesmo entendendo que era grave a "conspiração", sabia que precisava manter uma conexão com a Assembleia e o tom do relatório era chave nesse processo, pois era o documento oficial que retratava a província para o país e para o governo. Omitiu fatos, mas não deixou de registrar a pressão que sofria e as providencias que procurou tomar. No entanto, quando deixou o governo, ao entregar a presidência para seu sucessor, decidiu soltar a voz: "os estadistas que formam o gabinete de 29 de setembro não attenderam que a força moral do governo deve ser um dos elementos indispensáveis para bem governar o paiz", pois apoiaram a volta "triumphante de Manoel Alves Ribeiro", que logo outra conjuração formou "para o assassinato de vários cidadãos, cujo concerto infernal teve principio de execução na pessoa do juiz municipal.... tiro de pistola.... do qual por fortuna escapou"3. Chegou a citar no relatório, ressentido, trechos que o jornal $O$

2 Arquivo Publico do Mato Grosso, APMG, Secretaria do Governo, Correspondência com o Ministério da Justiça, est. 6, pasta 98, ofício de nov.1848. A conspiração era liderada por Manoel Alves Ribeiro, Chefe da Legião da Guarda Nacional, e pelo bacharel Ayres, ex-Chefe de Polícia (demitido por Oliveira, continuou como Juiz de direito) segundo o presidente estavam insatisfeitos com demissões, com a reforma que ele empreendeu nas eleições de vereadores e juízes de paz. Segundo Oliveira, o partido de Alves Ribeiro dominava sobretudo em Poconé e em Diamantino, "este individuo ainda crê que o Mato Grosso não he província de hum Imperio civilizado, mas sim huma fazenda de que ele pode dispor como dispoz da Fazenda Camapoã".

3 Relatório do Presidente e commandante das Armas da Província de Matto Grosso o Major Joaquim José de Oliveira apresentado ao seu successor o Excellentissimo Presidente e Comandante das Armas da mesma provincia o Coronel Fosé da Costa Pimentel, R. Janeiro, Typ Paula Brito, 1850, p.9. 
Brasil, porta voz do novo gabinete conservador, publicou contra ele ${ }^{4}$. O texto, fortemente político, foi impresso na Typografia de Paula Brito, na Corte, em 1850.

Também os relatórios dos ministros chegavam às mãos dos presidentes provinciais, escolher o vocabulário e a formulação desses documentos podia ser estratégico. José Bento da Cunha Figueiredo quando presidente de Pernambuco escreveu ao seu amigo e ministro da Justiça Nabuco de Araújo, em carta pessoal elogiando-o pelo "belo relatório" e agradecendo a menção à sua administração na província ${ }^{5}$ (Nabuco conseguiu assim acalmar José Bento que andava bem frustrado com pedidos não atendidos).

Quando um ministro, ou um presidente, ou o seu secretário, escrevia um desses documentos, sabia que os deputados e o povo das galerias não seriam o seu único público. Os relatórios circulavam pelo país por vias oficiais, o documento apresentado na Assembleia do Mato Grosso seria depois lido pelos presidentes de Alagoas, Rio Grande do Sul, Minas Gerais, Bahia. Essa circulação de narrativas sobre a administração pública ia conformando um vocabulário comum, um campo discursivo comum, e quem sabe uma expectativa comum. E conformava um conhecimento compartilhado sobre as diversas províncias.

Augusto Leverger, presidente do Mato Grosso, agradecia em correspondência do dia 10 de novembro de 1851 ao presidente de Pernambuco pelo envio de dois exemplares "dos Actos Legislativos dessa província, promulgados no corrente anno". ${ }^{6}$ No mesmo dia também

4 Em correspondência ao ministro da Justiça (Eusébio de Queirós) ele reclamou que o periódico O Brasil tinha tido acesso aos "fatos relatados na minha correspondência official, de que mostra achar-se instruido". Completava: "falta de lealdade que muito me doe". Nessa carta dizia "não sou Luzia nem Saquarema, nem sympathico com estas qualificações. Amo sinceramente o meu Paiz...”. APMG, Secretaria do Governo, Correspondência com o Ministério da Justiça, est. 6, pasta 98, 13/junho/1849.

5 IHGB, Coleção Sen. Nabuco, DL363.30, José Bento da Cunha Figueiredo, carta de 20/junho/1854.

6 APMG, Secretaria de Governo, Registro da correspondência, 1851-1857, Est. 6, pasta 120. Ofício de 10/nov/1851. 
agradecia ao presidente de Santa Catarina pelo envio das "duas coleções das Leis promulgadas pela Assembleia Legislativa" naquele ano e depois ao Rio de Janeiro, agradecendo o envio das leis e Regulamentos promulgados entre 1835 e 1850 naquela província.

$\mathrm{O}$ conjunto de leis aprovadas por cada assembleia chegava às demais províncias. As jurisdições consideradas abusivas decididas localmente podiam virar tema de debate. Explicita-se um campo sempre em construção e em disputa. Como André Machado mostrou, a Lei Provincial do Pará legalizando o trabalho compulsório indígena em 1838 causou forte repercussão na Assembleia Geral. ${ }^{7}$ Miriam Dolhnikoff também estudou conflitos desencadeados em torno das jurisprudências provinciais ou nacionais depois da Interpretação do Ato Adicional em $1840^{\circ}$. Expressando temor do que poderia sair ao final da sessão das Assembleias, o ministro da Justiça lembrava ao presidente do Mato Grosso em 1851 o emprego de "toda a sua influência" para tentar impedir que os deputados aprovassem a criação de novas freguesias e o aumento do ordenado dos funcionários públicos ${ }^{9}$. As assembleias provinciais, assim como o Parlamento, eram um campo do debate político estratégico no XIX.

Caso expressivo da conexão entre as partes, da circulação do debate e da dimensão potencialmente conflitiva de uma lei de âmbito provincial que atravessasse a Constituição está no decreto publicado por Honório Carneiro Leão quando presidente de Pernambuco em 1849. Não era tão fácil, mesmo para Honório, um dos políticos de mais prestígio naquele momento, administrar da maneira que ele queria. No dia 9 de novembro de 1849, publicou:

7 MACHADO, André "As interpretações dos contemporâneos sobre as causas da cabanagem e o papel do parlamento”, Revista de História, São Paulo, n. 175, jul-dez 2016. O Corpo de Trabalhadores era um dispositivo "legalizando o emprego compulsório da mão de obra de todos os homens, exceto os brancos, que não pudessem comprovar ocupação regular", p.312.

8 DOLHNIKOFF, Miriam, O pacto imperial, origens do federalismo no Brasil, São Paulo, Globo, 2005.

9 APMG, Secretaria do Governo, Correspondência do Governo com o Ministério da Justiça, 18471854. Est.6, pasta 98. 
O presidente da província considerando que os grupos reunidos nas matas do sul, debaixo do comando de Caetano Alves da Silva e do capitão Pedro Ivo Velloso da Silveira (...) não tem caracter algum politico; (...) resolve: Art. 1 1. Todas as pessoas que derem favor e ajuda serão considerados complices de taes crimes (...) Art. $3^{\circ}$. Os habitantes das matas do sul (...) desta província, que não quiserem compartilhar a sorte dos referidos bandidos, deverão retirar-se das matas até ao fim do corrente mez, apresentando-se ao comandante das armas (...) Art. $4^{\circ}$.(...) As guerrilhas que prenderem a qualquer dos chefes Caetano Alves ou o capitão Pedro Ivo, receberão uma gratificação e premio de oito contos de réis, e no caso se serem os ditos chefes mortos em acto de resistência, receberão quatro contos de réis $(. . .)^{10}$

Os liberais nomearam o ato de Honório Leão de Decreto de Sangue $e^{11}$ e vociferaram nos diversos jornais do país. A contrapartida precisou se organizar rapidamente. A matéria de primeira página do jornal Brazil, no Rio de Janeiro, vinte dias depois da publicação do decreto no Recife, já defendia o líder conservador, trazendo um título ousado, Cabeças a premio, o ponto central que motivara a fúria dos liberais. A matéria procurava defender a legalidade da decisão de Honório. Diferenciava essa batalha da Praieira, "o movimento politico cessou", agora eram apenas "homens ferozes que resistiram ao mais amplo e generoso perdão" ${ }^{12}$. Talvez não fosse à toa que os jornais da oposição gritassem já há algum tempo que havia uma terrível e particular "jurisprudência Honório-vasconcellina". ${ }^{13}$

O Correio Mercantil, principal jornal da oposição, no dia 29 de dezembro de 1849 publicou trechos de um manifesto assinado por Pedro Ivo e Caetano Alves, como resposta ao decreto de Honório. Come-

10 Resolução publicada no Diário de Pernambuco, edição n.252, sábado 10/nov/1849. Parte Oficial, Governo da Província.

11 Correio Mercantil, Domingo, 25/nov/1849, "um governo sem respeito à lei, à moral, à religião... tenhão nossos amigos resignação, valor e constância, que a patria sera salva...tanto mais o governo abusar do poder, violar a constituição e as leis do país, mais se aproximará de sua ruina". Além do prêmio em dinheiro, causou profunda indignação proclamarem reós de crimes os companheiros de Pedro Ivo, sem terem sido julgados, e ainda obrigar os habitantes das matas a deixarem suas casas.

12 Brazil, 29/nov/1849.

13 Diário Novo, Sábado 25/nov/ 1843. 
çavam por chamar Carneiro Leão de ditador, explicando que a causa deles era a da "liberdade contra a tyrania:

A coluna d'Agua Preta tem um caráter político, e esse tão nobre e elevado (...) nos querem reduzir a triste condição dos infelizes Polacos. Não o conseguirão (...) A constituinte é pois quem pode salvar o Brasil e pela sua convocação verteremos a ultima gota de sangue. Homens que nutrem tão nobres sentimentos não são assassinos, não são salteadores (... $)^{1 !}$

No primeiro dia do ano, na frente de toda a Assembleia, assim como das galerias lotadas, D. Pedro II na Fala do Trono referiu-se aos conflitos em Pernambuco, "os homens perdidos, que, surdos à voz da minha imperial clemência (...) procuram novamente perturbar a tranquilidade publica. $\mathrm{O}$ meu governo continua a empregar meios enérgicos para extinguir este gérmen revolucionário". ${ }^{14}$ A chancela final a favor de Honório Leão viria do próprio imperador.

Além da batalha na imprensa, abertos os trabalhos na Assembleia, os debates ferviam. O deputado liberal Souza Franco acusava o desrespeito à Constituição, Nabuco Araújo defendeu a atitude de Honório Leão. ${ }^{15}$ Honório Leão teve apoio de ministros importantes; em fevereiro escreveu uma carta pessoal agradecendo, comovido, o apoio que o ministro Paulino lhe confiara, em discurso na tribuna. ${ }^{16} \mathrm{~A}$ discussão sobre a aplicação das leis nas diversas localidades podia ou não acabar provocando a alteração da própria lei, conforme as forças políticas na arena.

Uma instituição central revigorada em 1842 pelos conservadores fazia parte do percurso de aplicação de uma nova lei: o Conselho de Estado. A consulta ao Conselho de Estado podia vir dos ministérios ou do Executivo, podia ser uma demanda por esclarecimentos jurídicos,

14 Fallas do Trono, desde o anno de 1823 até o anno de 1889, Rio de Janeiro, Imprensa Nacional, 1889, p.439/440.

15 Correio Mercantil, 22/jan/1850. O jornal publicou os debates da sessão do dia 21.

16 IHGB, Coleção Visconde de Uruguai, Carta de Honório Carneiro Leão. 16/fev/1850, “... assegurar-lhe que se acha gravado em minha memoria a parte do discurso que VE fez perante o Senado contendo a defesa dos meus atos como presidente desta Provincia". 
ou sobre as funções e competências administrativas. ${ }^{17} \mathrm{O}$ Conselho de Estado também exercia atividade reguladora, elaborando regulamentos e decretos, como por exemplo o regulamento das missões e catequeses de 1845, o da "Fundação de colônias militares nas províncias de Pernambuco e Alagoas", decreto de novembro de $1850^{18}$, entre muitos outros. Mesmo que o experiente Major Andrea tenha recomendado a fundação de apenas uma colônia militar entre as províncias de Alagoas e Pernambuco ao Conselho de Estado, "fazendo saber aos presidentes respectivos que tanto Pernambuco como Alagoas pertencem ao Imperio do Brasil ${ }^{19}$ o governo preferiu inaugurar duas, uma em cada província, para não mexer com suscetibilidades e facilitar a administração - reconheciam o campo local.

A regulamentação das leis e o estabelecimento de jurisdições passava muitas vezes por circuitos complexos. É revelador atentar para o processo de regulamentação e debate da nova legislação eleitoral aprovada em 1846 na Assembleia Geral durante o quinquênio libe$\mathrm{ral}^{20}$. Tendo entrado em vigência, houve um notável esforço de seguir

17 MARTINS, Maria Fernanda Vieira, A Velha arte de governar, um estudo sobre política e elites a partir do Conselho de Estado, 1842-1889, Rio de Janeiro, Arquivo Nacional, 2007, p.280-281. Ver também LOPES, J. Reinaldo, O Oráculo de Delfos: o Conselho de Estado no Brasil Império, São Paulo, Saraiva, 2010; e GARNER, Lydia M. N. In Pursuit of Order: a study in Brazilian centralization, the Section of Empire of the Council of State, 142-1889. Tese de doutoramento: The Johns Hopkins University, 1988.

18 Parte do debate sobre a elaboração desse regulamento está na coleção Visconde de Olinda, IHGB. No preâmbulo do Decreto publicado, vem a filiação legitimadora "Hei por bem, Tendo ouvido a Secção do Imperio do Conselho d'Estado, Approvar e Mandar que se execute o Regulamento que com este baixa, assignado pelo Visconde de Mont'alegre, do Conselho d'Estado, Presidente do Conselho de Ministros, Ministro e Secretario d'Estado dos Negocios do Imperio"

19 Francisco José de Sousa Soares de ANDREA, Carta ao Visconde de Olinda, respondendo a consulta...Coleção Marques de Olinda, IHGB, Lata 206, doc.6. 1850

${ }^{20}$ Como enfatiza Rodrigo Munari, seguindo perspectiva de Miriam Dohlnikoff, "a lei de 1846 reiterava o caráter eletivo das principais autoridades ocupadas com a organização e realização dos pleitos...é certo, assim, que o Partido Liberal não compartilhava das mesmas concepções que o Conservador a respeito do funcionário ideal que deveria estar a serviço da tarefa de construir o Estado-nação". p.103/104. Assim, a proposta de 1846 alteraria radicalmente as instruções concebidas pelo Partido Conservador em 1842. Ver MUNARI, Rodrigo Marzano, Deputados e delegados do poder monárquico: eleições e dinâmica política na província de São Paulo (1840-1850), Dissertação 
os procedimentos, listas de qualificação eram enviadas das localidades aos presidentes, corrigidas, procedimentos eram questionados, revistos. Um regulamento incorporando e resolvendo as dúvidas segundo orientação do Conselho de Estado foi rapidamente publicado (Decreto 480, 24/out/1846 ${ }^{21}$ ). Um mês depois, era estabelecido também pelo Conselho de Estado o valor do padrão da prata para o votante - seria o dobro do valor anterior, ou seja $200 \$ 000$.

As consultas feitas por presidentes sobre decretos ou leis eram enviadas pelo ministério do Império às demais províncias, fazendo com que as dúvidas e as respectivas decisões fossem conhecidas por todos, ajudando a balizar decisões. Em seu relatório de 1847, Joaquim Marcelino de Brito, ministro do Império, arrolou mais de uma centena de dúvidas enviadas das inúmeras freguesias do país sobre as eleições, com a solução dada pelo presidente para cada caso, e o julgamento dele, ministro, sobre cada uma dessas soluções dos presidentes: "foi acertada a decisão", "não foi acertadamente decidida por V.Ex."22. E esse documento circulou por todos os presidentes, que tinham suas decisões expostas, assim como o resultado final da avaliação que mereceram do ministro. Era um esforço e tanto para tolher condutas não regulamentadas.

De toda maneira, vale ressaltar como a participação nesse processo vinha desde o cidadão que enviava uma petição reclamando que a lei não tinha sido cumprida, passando pelos juízes de paz, juízes municipais, juízes de direito e as câmaras municipais. Havia debate, disputa, expectativas compartilhadas e apropriação dos procedimentos legais por setores mais amplos da população do que se costuma pensar. ${ }^{23}$

de mestrado, História, EFLCH, USP, 2017. DOLHNIKOFF, Miriam, "Governo representativo e eleições no século XIX", Revista do IHGB, 2018.

${ }^{21}$ Na letra da lei, está "solicitando a Camara Municipal da Cidade do Serrro, esclarecimentos (...) e convindo, para que a citada lei seja uniformemente executada em todo o Imperio (...)hei por bem, tendo ouvido a Secção do Conselho d'Estado, a que pertencem os Negocios do Imperio, Declarar:..."

22 Relatório do Ministro do Império, 1847.

23 Nesse sentido, ver trabalho de VELLASCO, Ivan, As seduções da ordem, violência, criminalidade e administração da justice, Minas Gerais, século 19, Bauru, EDUSC, São Paulo, ANPOCS, 2004. A 
Ilegalidades praticadas não eram passivamente aceitas, sendo objeto de denúncia. Como bem observou Rodrigo Munari depois de ampla pesquisa sobre as eleições da década de 1840 em São Paulo, "a construção de um regime representativo - no sentido da organização e prática do sistema eleitoral - não era problema restrito à esfera teórica dos legisladores, mas era uma questão pertinente também e das mais disputadas e debatidas, aos atores políticos de reduzidas circunscrições" ${ }^{24}$. Pudemos observar esse diálogo na correspondência dos presidentes quando encaminhavam as dúvidas ao Ministério do Império. Mas fica também claro nas revoltas populares de amplas dimensões contra leis consideradas abusivas, como a do Registro Civil de 1851, a da obrigatoriedade de licença da Câmara Municipal aos ganhadores de rua de Salvador em 1857, a Lei dos cemitérios de 1858, a Lei dos Pesos e medidas de 1872, a Lei da Cumbuca de 1874.

Novos atores viriam também testar o alcance das jurisdições provinciais e nacionais apropriando-se das leis e circulando pelo território. Ao longo da década de 1850 e 1860, lideranças indígenas passam, de maneira crescente, a procurar as capitais provinciais demandando seus direitos aos presidentes das províncias e também dirigem-se à corte, para falar ao Imperador. A maioria vai protestar contra o "esbulho" de suas terras, pedir demarcação. A chegada dos índios na cidade causava espanto. No dia 6 de abril de 1854, "neste momento, às três horas da tarde, aqui se aprezentarão onse Indios" ${ }^{25}$, escrevia o diretor geral dos Indios de Minas Gerais. Pelo visto, era das primeiras vezes que isso ocorria. Eram da "tribu dos Molalis aldeados em Santa Maria Maior, com o requerimento de queixa (...) expõem por si e por mais 70 da mesma tribu a ameaça que lhes tem feito de os privar da posse de terras (...)", o presidente pediu que o diretor de Indios desse roupas, panos e

documentação mostrou que houve uma busca pela resolução dos conflitos através do judiciário, legitimando a intervenção do Estado.

24 MUNARI, Rodrigo Marzano, Deputados e delegados....,p192.

25 Arquivo Público Mineiro, APM, SP508, Ofícios negócios eclesiásticos, catequese, 1854. Ofício de 6/abril/1854 ao presidente Dr. Francisco Diogo Pereira de Vasconcelos. 
dinheiro para regressarem à aldeia e pediu providências ao juiz municipal do Serro. ${ }^{26}$ Em julho do mesmo ano, outros 47 índios chegavam em Ouro Preto fazendo suas demandas. Em 1864 viriam ainda índios que não falavam português, "13 índios, 11 homens e duas mulheres, do aldeamento do Ribeirão do Capim, capitaneados por Joaquim de tal, que lhes serve de interprete" ${ }^{27}$ Manuel Valentim, líder indígena de longa trajetória (começou como guerreiro cabano), foi para o Rio de Janeiro em 1871 falar com o Imperador para reclamar da demarcação que privilegiou posseiros e não os índios do aldeamento. ${ }^{28}$

Nem sempre presidentes de províncias vizinhas concordavam sobre o modo de governar diante de uma crise compartilhada. Antonio Coelho de Sá e Albuquerque era presidente da Paraíba em 1852 quando estourou a revolta contra o registro civil. Enquanto o presidente de Pernambuco, Vitor de Oliveira, recomendou a suspensão provisória do regulamento $^{29}$, o da Paraíba mostrava-se preocupado com essa estratégia:

Esta Província, limitrophe da de Pernambuco (...) acompanha-a quase sempre em todos os seus movimentos populares (...) E tendo sido suspenso na Província de Pernambuco o dito Regulamento (...) a população desta por espírito de imitação começou a exigir impertinentemente e audaz a mesma providencia; eu porem entendi que oppondo-se o povo com armas à execução do Regulamento que elle apellidara $=$ Lei do Captiveiro, tocar o Governo prompta retirada seria reconhecer sua fraqueza, obedecer ao perigozo poder do povo, deixandolhe confirmados no espírito os prejuízos e preconceitos que elle nutre contra essa Lei de Progresso e civilização, e sobre tudo estabelecer um precedente funestissimo para o futuro.

26 APM, SP540, Registro de ofícios e mais atos do Governo sobre catequese (1854-1860), fl. $1 \mathrm{v}$.

27 APM, SG04, Livro para registro de correspondência da Diretoria Geral dos Índios, 1863-1869. Ofício de 6/julho/1864.

28 A reconstituição das disputas enfrentadas pelos índios do aldeamento de Escada e Riacho do Mato está na ótima pesquisa de SILVA, Edson Hely, O lugar do índio, conflitos, esbulhos de terras e resistência indígena no século XIX: o caso de Escada-PE (1860-1880), Dissertação de mestrado, História, UFPE, Recife, 1995.

29 Vítor de Oliveira mandou ofício circular orientando párocos e juízes de paz a seguirem com a prática tradicional até que pudessem cumprir a lei, ofícios de 3/jan/1852 e de 4/jan1852, Ofícios dos presidentes, Pernambuco, Ministério da Justiça, IJ253,ANRJ. 
E seguia, especificando a percepção da conjuntura de lutas em que viviam

(...) Como Vossa Excelência sabe o prezente anno é abundante em ajuntamentos populares; eleições de Juizes de Paz, de Vereadores, de Eleitores, e de Deputados hão de ter lugar, e num anno desses reconhecer o Governo como legitimo o perigosíssimo principio da resistência armada às leis, (...) num anno desses o Governo deixar vivo no espírito do povo um prejuízo que se traduz por fanatismo, é por nas mãos dos patriotas um instrumento terrível contra as instituições do paiz ${ }^{30}$.

A carta confidencial era para o ministro da Justiça e conselheiro de Estado Euzébio de Queirós. Sá e Albuquerque era amigo pessoal de Nabuco de Araújo, era quadro importante dos conservadores - para ele, o maior problema não parecia ser a falta do registro civil ou do censo mas dar a vitória aos "povos", pensava na luta política, preocupava-se com o ano eleitoral. No entanto, os líderes saquaremas na Corte, embora provavelmente concordassem com ele - haja visto o empenho para, nos anos seguintes, garantir a presença de oficiais do Exército em postos da polícia civil nos interiores da Paraíba, Pernambuco, Alagoas, assim como a perseguição aos grupos políticos regionais dissidentes - avaliaram de modo diverso a resolução daquele conflito, aquela lei não podia ser cumprida à força, não naquela conjuntura política ${ }^{31}$. Quando escrevia, o presidente da Paraíba ainda não sabia que a execução da lei tinha sido suspensa pelo gabinete no decreto 907, do dia $29 / \mathrm{jan} / 1852^{32}$.

Pesquisar o percurso de uma Lei, desde os vários projetos, até o processo de regulamentação, pode explicitar um quadro de tensão ou

30 Ofício confidencial de Antonio Coelho de Sá e Albuquerque para o Ministro da Justiça, $7 /$ fev/1852. Ofícios dos presidentes, Ministério da Justiça, Paraíba, IJ 798, ANRJ, 1850-1856.

31 Sobre a revolta e a postura do gabinete e dos presidentes das províncias ver OLIVEIRA, Maria Luiza Ferreira de, "Resistência popular contra o Decreto 798 ou a "lei do cativeiro": Pernambuco, Paraíba, Alagoas, Sergipe, Ceará, 1851-1852”, In DANTAS, Monica D. (org.) Revoltas, motins, revoluções, homens livres pobres e libertos no Brasil do século XIX, São Paulo, Alameda, 2011, p.391-428.

32 Coleção de Leis do Império do Brasil, 1852, p.19, vol.1, pt.II. 
de disputa politica. A Lei de Terras, como já foi exaustivamente discutido pela historiografia, foi regulamentada apenas em 1854 (a lei foi aprovada em 1850, depois de anos de debate), foram inúmeras as dúvidas encaminhadas pelas administrações locais sobre procedimentos, mas pouco era respondido. Até 1854, apenas uma decisão foi publicada trazendo a lei no debate, a n.172, pelo Ministro do Império, Visconde de Monte Alegre, autorizando a Repartição Fiscal da província do Ceará no prosseguimento do sequestro pelo governo da província das terras dos Indios, "em consequência de não existirem ahi hordas de Indios Selvagens" as terras deveriam ser "consideradas como devolutas e como tais aproveitadas na forma da Lei n.601 de que incluso se remete a vEx hum exemplar impresso para seu conhecimento" "33. A decisão foi publicada em outubro, um mês depois da aprovação da lei, articulando os dois temas e avalizando uma prática. A Lei de Terras teve como efeito ajudar na destituição das terras dos aldeamentos indígenas, não regularizou o sistema fundiário (para isso não houve esforço do governo conservador pelo cumprimento da lei) ${ }^{34}$. Sobre a nova Lei da Guarda Nacional, também de 1850, também houve questionamentos diversos; foram publicadas poucas decisões, como a n.255, de 22/

33 Colleç̧ão das Decisões do Governo do Imperio do Brasil, Tomo XIII, 1850. Rio de Janeiro, Typographia Nacional, 1851, p.148/149.

34 A historiografia há tempos documentou o não cumprimento da lei - atribuindo diferentes explicações para esse processo. Para José Murilo de Carvalho, a lei atendia aos anseios dos fazendeiros de café do Rio de Janeiro preocupados com a imigração subsidiada e foi boicotada pelo resto do país, mostrando tanto a incapacidade do governo central para lidar com essa resistência quanto o poder não tão amplo dos cafeicultores. CARVALHO, J. M., Teatro de sombras: a política imperial, Rio de Janeiro, Iuperj/Vértice, 1988, p.84-106. Mais recentemente, Tamis Parron agregou novo ingrediente à leitura, atribuindo importância ao momento da apresentação do projeto, 1842, e o esforço para aprovação da lei à atuação de Vasconcelos e do grupo saquarema, que, "em face do abolicionismo internacionalista, de 1839 em diante, o projeto da Lei de Terras foi uma tentativa articulada de institucionalizar o transplante de mão de obra barata para o Brasil, incluídos aí africanos", PARRON, T., A política da Escravidão no Império do Brasil, Rio de Janeiro, Nova Fronteira, 2011, p.218. Quem acabou, muitas vezes, demonstrando interesse na aplicação da lei foram pequenos proprietários que buscavam registrar suas posses como chamou a atenção MOTTA, Márcia. Nas fronteiras do poder, conflitos de terras e direito agrário no Brasil de meados do século XIX, Rio de janeiro, Vicio de Leitura, Arquivo Publico do Estado do RJ, 1998, p.161-187.

dossiê Jurisdições, 
out/1851, esclarecendo sobre a responsabilidade das despesas quando a guarda estivesse destacada, ou o Aviso de 11/set/1851, sobre a não isenção "dos sacristas das Matrizes" para o serviço na Guarda; em 1853 mais duas decisões foram publicadas sobre a lei, a n.160 e a n.171. Nada que se compare, de toda maneira, às respostas do governo em relação aos questionamentos sobre a legislação eleitoral: foram seis decretos publicados sobre a lei de 1846 até o final de 1847 e diversas decisões publicadas nos anos subsequentes.

No Rio de Janeiro e em algumas outras cidades do país, um cidadão poderia ter acesso à Collecção das Leis do Império do Brasil (com os decretos e as leis) e à Collecção das Decisões do Governo do Império do Brasil, impressos pela Typographia Nacional. A publicação começou a ser feita em 1842, sempre referente ao ano anterior.

A circulação de mapas entre as províncias também fazia parte desse processo de autoconhecimento das partes ocorrido nas décadas de 1840-1850. O presidente do Mato Grosso escrevia ao presidente do Piauhy agradecendo pelo envio do mapa "demonstrativo das distancias pelo caminho mais curto entre as cabeças de Comarca dessa Província e entre ellas e as de suas confinantes nas outras", ${ }^{35}$ e ao presidente de Goyaz que também enviara um mapa, nos mesmos termos. ${ }^{36}$ Houve, no plano das províncias, uma preocupação nos anos 1830 e 40 de reforçar a construção de estradas que comunicassem com o centro - como deixa claro o plano Viário de 1835 promulgado pela Assembleia de Minas Gerais que colocava a centralidade de Ouro Preto no sistema viário provincial e previa erguer quatro estradas em direção à Corte (Lei n.18, 1 abril 1835).

A construção de estradas era atribuição provincial, mas havia empreitadas conjuntas entre as províncias, como na estrada para ligar a capital do Espirito Santo até a fronteira de Minas Gerais ao norte, nos

35 APMG, Secretaria do Governo, Registro da correspondência entre o presidente e o Exterior, 1851-1857, Estante 6, pasta 120, Ofício de 20/out/1851.

36 APMG, Secretaria do Governo, Registro da correspondência...., 1851-1857, Est.6/120, 18/ $\mathrm{jan} / 1852$ 
sertões do Mucuri. O empreendimento nasceu conjunto, mas houve ruídos nos combinados. Em outubro de 1847, o diretor do aldeamento Manhuassu escrevia nervoso reclamando ao presidente por ter chegado no aldeamento o empreiteiro da estrada, o mineiro Francisco de Paula Cunha, dizendo que tinha ordens do governo do Espirito Santo para levar índios para a obra da estrada. Foram levados do aldeamento os índios em idade para o trabalho, deixando abandonadas as plantações. O presidente de Minas recebeu carta do seu vizinho do Espirito Santo, Luiz Pedreira do Couto Ferraz, lembrando-o do contrato que conjuntamente fizeram com o empreiteiro, de que Minas forneceria os índios, o contratador do serviço o sustento, e o governo do Espirito Santo daria o vestuário, argumenta que "foi nessa clausula baseada o referido contrato, é o único meio de levar a efeito esta importante obra". ${ }^{37} \mathrm{O}$ governo de Minas mandou voltarem 22 índios ao aldeamento, deixando 80 nos trabalhos da estrada. Couto Ferraz, no entanto, escreveu em seu relatório para a Assembleia Legislativa do Espirito Santo, em 1848: "se não fossem por ordem do governo de Minas retirados, por serem precisos no seu aldeamento, os Indios que de tão bom grado havia prestado (...) estaria hoje (essa importante estrada) de todo concluída...". ${ }^{38}$ Couto Ferraz decidiu então contratar outro empreiteiro com prática de lidar diretamente com os botocudos, para não precisar do aldeamento. Era um esforço colonizador em pauta: pacificar índios, conseguir mão de obra para construir estradas, potencializar a circulação de pessoas, produtos, saberes.

Como mostrou Beatriz Magnomian, o governo conservador acabou com o tráfico, manteve intacta a escravidão e organizou o escoamento de centenas de africanos livres, fazendo concessões de trabalhadores para empreendimentos de interesse do governo, "como a abertura da estrada entre São Paulo e Mato Grosso, que recebeu 61 africanos....a província de São Paulo receberia outros 64 em dezem-

37 APM, PP4, Cx 2, Ofício de Luiz Pedreira Couto Ferraz, 17/out/1847

38 Relatório Apresentado à Assembleia pelo presidente da provincia do Espirito Santo, dr. Luiz Pedreira do Couto Ferraz, março/1848, p51, 52. 
bro de 1851"39. Essa articulação era feita pelo ministério da Justiça. Em 1852, o presidente da Bahia e líder conservador Gonçalves Martins destinou outros 100 para obras de drenagem em Salvador. Como postula a autora, para os africanos livres, "as chances de desfrutar a liberdade adquirida com base na legislação diminuíram até quase desaparecer" ${ }^{\prime 4}$. A busca por mão de obra para os almejados melhoramentos materiais do país e ações nas fronteiras passava por arranjos envolvendo o trabalho forçado de índios e africanos.

\section{Na guerra: dinheiro, homens e armas}

No momento do perigo, nas guerras, a correspondência entre as províncias envolvidas se intensificava. Trataremos aqui da comunicação entre Pernambuco e Alagoas durante a Guerra do Jacuhype, em 1845. Caetano Maria Lopes Gama, político de prestígio, foi enviado para Alagoas para anistiar os rebeldes da sedição de 1844 e pacificar a província conflagrada. O trabalho não foi, no entanto, completo pois restou Vicente Ferreira de Paula e "seus sequazes" nas matas de Jacuípe. Se Vicente vinha sendo "tolerado" desde 1835 naquela região, a situação agora se complicava pois o líder popular tinha invadido a capital no comando de pelo menos 600 homens, compondo as forças rebeldes. No dia 10 de janeiro de 1845, Lopes Gama ainda tentando evitar uma guerra nas matas, escreveu ao seu vizinho em Pernambuco, Thomas Xavier Garcia de Almeida, pedindo "com urgência a quantia de quarenta contos de reis para despesas que não se podendo adiar (...) darei conta ao Governo Imperial como me cumpre"41. Lopes Gama devia confiar no seu capital político para pedir em termos tão imperiosos quantia alta e ser atendido tão rapidamente. Exatos 11 dias depois, no dia 21 de janeiro, Lopes Gama já escrevia:

39 MAMIGONIAN, Beatriz G., Africanos livres, a abolição do tráfico de escravos no Brasil, São Paulo, Cia das Letras, 2017, p249.

40 MAMIGONIAN, Beatriz, Africanos livres..., p.90.

${ }^{41}$ Arquivo Publico do Estado de Pernambuco Jordão Emerenciano, APEJE, PP16, fl.6 e 7, ofício de $10 /$ jan/1845. 
"agradecendo em extremo a prontidão com que VExcia se dignou satisfazer a requisição, enviando-me a 14 pelo Capitão Tenente Guilherme Lassance, comandante do Vapor Guapiassu, a quantia de 40 contos de réis em notas que recebi e mandei entregar à tesouraria da Fazenda para ocorrer às extraordinárias despesas a cargo do Ministerio da Guerra nesta Provincia"

Em meados de fevereiro ele pediria mais trinta contos de réis, dessa vez justificando que os rendimentos da província tinham se desorganizado com "as perturbações que nella tiveram lugar em o anno próximo passado". Também recebeu o dinheiro em seguida. Poucos dias depois, no dia 24 de fevereiro, avisava consternado: "conhecerá V. Excia que a guerra é já inevitável, pois que o fugitivo caudilho despistou por meio de guerrilhas que mandou colocar nas mattas de Jacuipe, a entrada de nossas Forças". Todo o esforço rápido e conjugado não surtiu os efeitos esperados. Tinham sido transferidos dos cofres de Pernambuco para o de Alagoas 70 contos em menos de um mês - quantia elevada. Sabemos que desse dinheiro quatro contos tinham sido prometidos por Lopes Gama para quem capturasse "o caudilho". Era quantia muito alta (comprava 10 escravos jovens na época) e, no entanto, ninguém entregou Vicente Ferreira de Paula às autoridades ${ }^{42}$.

As cartas revelam a materialidade da circulação dos recursos e dos fluxos decisórios. O presidente de Pernambuco agiu rapidamente, sem ter tempo de consultar o ministério na Corte - e o de Alagoas contava com essa ação. Provavelmente ambos soubessem que uma guerra naquele momento seria uma péssima notícia para o gabinete. Lopes Gama já era saudado como o pacificador e queria manter esse título. ${ }^{43}$

${ }^{42}$ Um estudo detalhado sobre os conflitos nas matas está em OLIVEIRA, Maria Luiza F. de, "As Guerras nas matas de Jacuípe”, Revista de pesquisa histórica CLIO, n.33.2, UFPE, 2015.

43 ANRJ, IJJ (9) 282, fl.180, 181, 182. Lopes Gama encaminhou cópias de saudações recebidas de várias câmaras municipais reunidas em sessões extraordinárias, destacando a habilidade do novo presidente e agradecendo por seu empenho e eficiência na "pacificação". Na noite do dia nove de março houve um baile em que ele esteve presente, o Comandante das Armas, o Chefe de Polícia, a "brioza oficialidade da marinha, reunidas as principais famílias da capital", e foi inclusive cantado um hino para agradecer Lopes Gama e o Imperador por "amnistiar os Alagoanos, salvando-os 
O apoio de Pernambuco não foi só com dinheiro, mas também com farinha enviada no início de março para as tropas, material bélico em abril ${ }^{44}$ e depois homens. Mas havia jurisdições que não podiam ser quebradas, e um dos problemas enfrentados no esforço de guerra eram as frequentes deserções dos guardas nacionais que aproveitavam-se da situação da fronteira para ganhar tempo e chão. O presidente de Alagoas escreveu preocupado pois tivera notícia do "indiferentismo" das autoridades locais em Pernambuco, desertores não eram "inquietados pela polícia", ${ }^{45}$ e o pior era que muitas vezes o desertor levava armas consigo.

No dia 17 de abril, o vice-presidente e militar Brigadeiro Henrique M. d'Oliveira Lisboa, que assumira o comando da guerra e da província, escreveu uma carta para o seu vizinho bastante irritado, nem um pouco constrangido diante de toda a ajuda já fornecida por Pernambuco. Dizia que "nossas forças" tinham "acossado Vicente e seus homens" para fora da fronteira, mas a falta de homens em Pernambuco tinha permitido ao "caudilho" escapar. Terminava sugerindo ao colega "dar aquellas providencias que o caso urge, (...) mostrar o zelo pelo amor da ordem". ${ }^{46}$ A carta incomodou, o presidente de Pernambuco justificou-se dizendo que a acusação era sem fundamento, o grande impasse era que ele não conseguia adesão dos habitantes dos entornos de Água Preta pois eram contra o governo, nenhum apoio davam ao esforço de guerra, era difícil mobilizar a Guarda Nacional pois achavam-se todos "indiferentes às ordens do governo, ninguém movendo forças". O presidente Thomaz Xavier d'Almeida reconhecia que era difícil o controle sobre a província, ele não era querido pelos liberais e pelos praieiros, pois tinha sido um dos carrascos de $1824 .{ }^{47} \mathrm{~A}$

da conflagração horrível". Houve também um beija-mão do presidente. Os rituais em torno do presidente dão uma dimensão da simbologia do cargo.

${ }^{44}$ APEJE, PP 16, fl.65, Ofício de 10/abril/1845, "não havendo arsenal nem laboratório nessa Província"

45 APEJE, PP16, fl.39, Ofício de 10/marco/1845, Caetano M. L. Gama.

46 APEJE, PP 16, fl.74, Ofício de 17/abril/1845.

47 QUINTAS, Amaro, “O Nordeste, 1825-1850”, In Sérgio Buarque de Holanda (org.) O Brasil Monárquico, Dispersão e unidade, HGGB, T.II, 2.vol., São Paulo, DIFEL, 1964, p.235. 
falta de alianças naquela região, bastião futuro da Praieira, dificultava a sua vida.

Henrique d'Oliveira avisou também que não podia enviar as duzentas praças do $4^{\circ}$. batalhão de artilharia que Pernambuco requisitava,

"pois careço de ordem do Ministro da Guerra, e mesmo que não fosse por esse motivo estaria impossibilitado de se desfazer destas praças, por terem marchado d'aqui duzentas para o Ceará, pelo que não tenho a superabundância de tropas que V.Ex. presume". ${ }^{48}$

Era recorrente a briga pelas tropas, era apertada a contabilidade e havia disputa, cada presidente puxando de um lado, para garantir a disponibilidade de batalhões de primeira linha. A circulação dos batalhões e dos oficiais era constante. As tropas eram removidas, devolvidas, oficiais deslocados, o presidente da província em geral pouco podia fazer. Podia, sim, opinar e tentar negociar, mas a logística era delicada. O Comandante das Armas de Pernambuco, em outubro de 1853 ponderava ao presidente que as tropas do Batalhão n.11 de Infantaria se achavam destacadas no Recôncavo e seriam encaminhadas para o Pará, recomendava a vinda para Pernambuco do Estado maior do $8^{\circ}$. Batalhão que permanecia em Alagoas, deixando ali um destacamento de 50 praças. O Comandante de Armas terminava dizendo que se ele concordasse com a sugestão, "terá a bondade de leva-la ao conhecimento do Exmo Ministro da Guerra". 49

Se fossem políticos de prestígio, teriam mais autonomia para manobras ajustadas entre eles. Em 1856 o presidente de Pernambuco trocou metade de um batalhão com Alagoas pois os que estavam em Recife "mostraram-se muito animados com o discurso do liberal Brandão", estavam "contaminados do espírito político", era justamente a

4 APEJE, PP 16, fl.121, Ofício de 3/junho/1845.

49 ANRJ, IG (1) 73, Correspondência de Pernambuco ao Ministro da Guerra, Ofício do Comandante das Armas ao presidente da Província de Pernambuco, 25/out/1853. 
época das eleições. Ele decidiu por essa manobra com o colega vizinho e depois comunicou ao ministro Caxias, contando com a aprovação.

A jurisdição sobre as forças armadas no Império era do Ministério da Guerra - e o período de reformas levadas a cabo pelos conservadores acentuou esse aspecto - ao longo da década de 1840 e 1850 há um constante aumento dos efetivos e do orçamento do Exército e do Ministério da Guerra ${ }^{50}$. O processo de nacionalização do Exército para combater de maneira mais efetiva as revoltas era já uma realidade nos anos $1850^{51}$. A naturalidade de 10 oficiais que passaram por inspeção de saúde em Pernambuco em 1853 revela de maneira eloquente essa circulação, cada um deles tinha vindo de um local: Pernambuco, Africa, Bahia, Maranhão, Sergipe, Ceará, S. Paulo, Minas e Rio de Janeiro ${ }^{52}$.

Mesmo a Guarda Nacional tinha administração supervisionada, o ministério referendava as nomeações para o comando. José Bento quando na presidência de Pernambuco empenhou-se na reorganização da Guarda Nacional, ia prestando contas a Nabuco, pedindo apoio financeiro, pedindo nomeações, indicando nomes. Mesmo com o apoio de Nabuco, ministro da Justiça, em fevereiro de 1854 ele escrevia decepcionado ao Ministro da Guerra, "mandei imediatamente dissolver o destacamento, resignando-me a sofrer as consequências...". ${ }^{53}$ Destacar a Guarda Nacional, desmobilizar a guarda, eram ações que necessitavam do aval do ministério da Guerra, pois os guardas desta-

50 SOUZA, Adriana Barreto de, O Exército na consolidação do Império, um estudo histórico sobre a politica militar conservadora, Rio de Janeiro, Arquivo Nacional, 1999.

51 RIBEIRO, José Iran, O Império e as revoltas, Estado e nação nas trajetórias dos militares do Exército imperial no contexto da Guerra dos Farrapos, R. Janeiro, Min. da Cultura, Arq Nacional, 2013 p/56-57.

52 ANRJ, IG (1) 73, Pernambuco ao Ministro da Guerra, março de 1853. A naturalidade do africano está assim descrita no documento, sem indicação da região no continente. Discussão mais detida sobre o projeto político da adoção dos corpos móveis no Império está no texto de OLIVEIRA, Maria Luiza F., "As colônias militares, a circulação e o enraizamento. Embates na construção do Estado no Brasil, 1840-1870", In SOUZA, Adriana Barreto de et alli, Pacificar o Brasil, das Guerras Justas às UPPs, São Paulo, Alameda, 2017.

53 ANRJ, IG (1) 73, 1853-58, Ofício de 11/março/1854, José Bento inclusive argumenta que vinha avisando ao Ministro da Justiça dos destacamentos que ele enviara ao interior da Província, por isso a capital estava desguarnecida (apenas 600 homens de linha...) 
cados como corpo recebiam soldos pagos por essa pasta, e isso só era permitido "na hypothese de operação militar para defesa de direitos Nacionais", como explicou o ministro ao presidente de Pernambuco.

Algumas situações no uso de forças armadas explicitavam a permanência de práticas que iam sendo enquadradas ou reelaboradas no novo cenário jurídico administrativo do Estado nacional. Bandeiras contra os índios eram organizadas no âmbito provincial e o presidente da província dava conta ao ministério da Justiça de suas ações. O embate de procedimentos e posturas fica claro na província do Mato Grosso. Por vezes a emoção eliminava os filtros e podemos testemunhar, sem máscaras, o projeto de extermínio. José da Costa Pimentel, presidente da Província, escreveu uma carta muito dramática ao ministro Eusébio de Queirós, no dia 16 de outubro de 1849:

"penetrado da mais pungente dor, participo a VEx que o 2․ Tenente Antonio Correa da Costa Pimentel foi assassinado pelos bugres Coroados, atravessado com huma frecha, estando a dormir na margem do rio Tiquira (...) restarãolhe apenas dex horas de pesada vida para misturar suas dores physicas com as moraes (...) Poucos dias antes havião esses tigres de figura humana redusido a cinzas hua fazenda do Capitão Antonio José da Silva nesse mesmo lugar (...) tenho ordenado a expedição de 3 bandeiras de 50 homens cada huma, afim de exterminar absolutamente semelhantes feras". ${ }^{54}$

O tenente morto era o seu filho. Ele desumanizava os índios para justificar o extermínio, como há 300 anos, depois comparava o que a província passava a uma catástrofe natural, "um terremoto, uma inundação", sob risco de desaparecer, se nada fosse feito, do mapa do Brasil. No dia 5 de novembro, em novo ofício, fala das duas bandeiras enviadas "para os exterminar, e assim desinfestar as estradas que se dirigem a essa Corte". Pois os índios Coroados tinham declarado guerra aberta a todos "os moradores e passageiros das estradas que se dirigem a Goyaz e a S. Paulo, atacando, roubando e incendiando; dispersan-

54 APMG, Secretaria do Governo, Correspondência oficial do Governo com o Ministério da Justiça, 1847-1854, Estante 6, pasta 98. Ofício de 16/out/1849. 
do os escravos". ${ }^{55}$ Em dezembro já tinha notícias das duas bandeiras, "duas grandes aldeias forão batidas e os Indios bem castigados". ${ }^{56}$ No final de fevereiro pedia apoio ao governo, dizendo que toda a verba da rubrica Cathequese e Civilisação de Indios tinha sido gasta nas bandeiras, e os "selvagens Indios Coroados continuavão nas suas devastações". Interpretação bem livre tinha o presidente feito da rubrica.

Foi só no dia 20 de março, cinco meses depois da primeira e apaixonada notícia das bandeiras organizadas por Pimentel, que o governo se manifestou em ofício ao presidente do Mato Grosso. Mesmo com os correios demorados para o Mato Grosso, era muito tempo. Um mês depois de enviada do Rio de Janeiro a carta chegou e Pimentel já respondia: "recebi hoje (...) fiquei com grande magoa sciente de que o Governo de S. M. O Imperador não aprovava esta medida por julgal-a hum excesso de rigor para com esses ferozes e indomáveis indígenas, que desde o descobrimento desta Província tem-se mostrado intratáveis". Justificando-se, fala que quase todos os antecessores dele tinham lançado mão dessa medida, "que está nos limites da lei, e dos antigos estylos desta Provincia (...) reclamada pela lei da necessidade". ${ }^{57}$ Afirmava que não tinha sido o espírito de vingança por ter perdido o filho, mas agira pela necessidade de manter a província conectada e proteger o seu comércio. E, sobretudo, as bandeiras tinham saído com "instruções desapaixonadas dadas pelo Chefe de Policia", e não teriam cometido barbaridades, apenas afastado os índios para o interior, protegendo a estrada. Duas crianças capturadas estavam sendo criadas "no maior mimo". ${ }^{58}$ Invocava também a sua ficha pública na administração de Minas Gerais e de Pernambuco, como homem "amante da moderação e da paz”, as duas palavras mágicas do momento. Não há mais registros de broncas ou reprimendas a Pimentel que seguiu na administração do Mato Grosso até fevereiro de 1851.

\footnotetext{
55 APMG, SG, Corresp. Gov. Min. da Justiça, 1847-1854, Est. 6, pasta 98. Ofício de 5/nov/1849. 56 APMG, SG, Corresp. Gov. Min. da Justiça, 1847-1854, Est. 6, pasta 98. Ofício de ?/dez/1849.

57 APMG, SG, Corresp. Gov. Min. Justiça, 1847-1854, Est. 6, pasta 98. Ofício 21/abril/1850.

58 APMG, SG, Corresp. Gov. Min. Justiça, 1847-1854, Est. 6, pasta 98. Ofício 22/junho/1850.
} 
O novo presidente, o capitão de Fragata Augusto Léverger, militar, logo que assumiu respondeu ao Aviso que recebeu do Ministério pedindo cautela com bandeiras, expediente que deveria ser usado apenas quando os Índios estivessem armados e ameaçando a segurança. Léverger mostrou intimidade com a província, falou sobre os diversos grupos indígenas, argumentou que muitas vezes antes as armas tinham sido importantes como primeira etapa para pacificar grupos indígenas, mas que no caso dos Coroados não adiantava. Mesmo com todas as atrocidades cometidas pelas ultimas bandeiras (segundo "era voz publica"), ao invés de se assustarem só ficaram mais bravos. Diz que só faria uso de uma bandeira se não tivesse outra escolha, mas agiria de forma diferente, buscaria trazer adultos presos, "embora fique mais dispendioso", nem que seja necessário "oferecer hum premio por cada Indio que me for apresentado vivo e são". Assim ele poderia ensinar português aos prisioneiros, fazê-los de intermediários para chamar os outros e convencê-los que "só queremos paz". ${ }^{59} \mathrm{O}$ Ministério aprovou essa estratégia e destinou dois contos para que ele pudesse prometer um prêmio pelos índios capturados vivos e sãos. Léverger respondeu que quando viesse a oportunidade de capturar índios bravios ele então o faria e perguntou qual seria a rubrica regular para ele custear a eventual bandeira, já que era irregular usar a da Cathequese e civilização, do Ministério do Império. Tratava-se de regulamentar e ordenar esse processo, ao fim e ao cabo reconhecido como o melhor. E o método das cabeças a prêmio continuava fazendo sucesso com esse gabinete.

Além das bandeiras, as províncias podiam criar forças policiais próprias, internamente - atribuição que era do legislativo. No entanto, Joaquim José de Oliveira teve autonomia para criar sozinho uma Guarda de Segurança Pública no Mato Grosso para prevenir uma revolta armada na província em 1848 - decisão pela qual prestou contas e pediu aprovação. ${ }^{60}$ Desde o Ato Adicional, as Assembleias

59 APMG, SG, Corresp. Gov. Min. Justiça, 1847-1854, Est. 6, pasta 98, Oficio 20/maio/1851.

60 APMG, Secretaria do Governo, Corresp. Mini. Justiça, Est.6, pasta 98, Ofício de 29/nov/1848, fl.24 a 25v. Preocupou sobremaneira o presidente a transferência da Tipografia da capital para a 
provinciais podiam e deviam criar forças policiais para o auxílio da manutenção da ordem interna, e a Interpretação do Ato não alterou essa atribuição. ${ }^{61}$ De toda maneira, mesmo que as províncias tivessem forças criadas localmente, nesse período de revoltas e de guerras, no momento do perigo, os presidentes sempre pediam pelas tropas de linha, consideradas as mais eficientes. As outras forças apoiavam a segurança das cadeias, o policiamento local, eventualmente apoiavam nos conflitos com os índios, mas não eximiam os governos provinciais das tropas estruturadas e comandadas pelo centro - pelo menos não nas décadas de 1840 e 1850.

Ao lermos a correspondência dos presidentes de Pernambuco durante as décadas de 1840 e 1850 percebemos que escreviam para todos, tanto as protocolares cartas informando da tranquilidade pública, "a província permanece em paz", até temas graves. Um exemplo está na carta do presidente do Maranhão de outubro de 1846, agradecendo pela comunicação do presidente de Pernambuco sobre "a reunião secreta de pretos desta cidade (...) não podendo por ora suspeitar que alguma relação tenha para esta província tão extravagante seita, bem que não seja para despresar, fico todavia de sobre-aviso". ${ }^{62}$ Ele avisou ao presidente do Maranhão por carta, mas essa seita, no entanto, não foi para as páginas do seu relatório oficial daquele ano. Imprimir conflito no relatório era amplificá-lo e perder a oportunidade de escrever a tão desejada frase: "a província permanece tranquila", o passaporte da boa administração. Esses administradores também trocavam experiências, como Antonio Manoel Campos Mello presidente de Alagoas ao alertar o vizinho sobre a diminuição do crime depois que ele vinha

vila de Poconé, efetuada pelos rebeldes.

61 Ver DOLHNIKOFF, Miriam, op, cit., p. 194-197. A autora fala da importância dessa força como instrumento nas mãos das elites provinciais para manutenção da ordem interna, citando Pernambuco. Para as revoltas maiores do período, tanto a Praieira, como a Guerra de Água Preta, ou Guerra dos Marimbondos ou a Guerra do Jacuipe, a Força Policial não aparece na documentação. Resta saber em que situações era utilizada. Nos anos 1850 vários presidentes mantém tropas do Exército ocupando o interior. Esse é um tema que carece de estudos mais aprofundados.

62 APEJE, PP17, fl.66, Ofício do presidente do Maranhão Joaquim F. de Sá, 4/out/ 1846. 
tentando "o desarmamento geral da Província, fazendo dispersar reuniões armadas" $" 63$, como quem aconselha Pernambuco a fazer o mesmo. O principal assunto que movia a correspondência eram informações sobre soldados desertores, circulação de rebeldes, formação de quilombos, notícia sobre o roubo de negros livres para a escravização ilegal, circulação de cédulas falsas, e também pedidos de apoio com a remessa de alimentos, em geral a tão importante farinha.

\section{A farinha e o socorro médico}

Em finais de 1855 manifestou-se uma brutal epidemia de cólera em Pernambuco. O presidente da província avisava angustiado que "entre o desejo que tenho de poupar os dinheiros públicos, e a persuasão em que o povo esta de que o Governo deve cural-o a todo custo, já não sei bem como me possa haver ${ }^{64}$ ". A ideia de que o governo em casos de doenças epidêmicas devia cuidar dos pobres, fornecer socorro, estava em pauta e em disputa. Em outra carta, já conformado com esse papel, afirmou: "o governo talvez venha de arrepender-se de haver feito do cholera hua moléstia official, encarregando-se de curál-a: o futuro o mostrará" 65 .

A epidemia grassava, era fortíssima, faltavam médicos ${ }^{66}$, alguns desistiam das comissões, outros exigiam pagamentos altos, o Governo queria obrigar os boticários a ficarem abertos até meia-noite, mas "al-

${ }_{63}$ APEJE, PP17, fl.273, Carta de 10/fev/1846.

64 ANRJ, IJJ (9) 255, Carta de José Bento da Cunha Figueiredo para Couto Ferraz, Ministro do Império, 13/fev/1856. Conta que os seis médicos vindos da Bahia pediram cada um 3 contos de réis mensais, alem de casa e transportes. Por isso ficou angustiado, viu-se forçado a aceitar "até para não me expor aos motejos da população que já me taxava de mesquinho". De fato, o valor era muito alto.

65 ANRJ, IJJ (9) 255, fl.54. Começa essa carta a Nabuco desesperado, reclama de dor de cabeça, da covardia dos médicos, da guerra com a Comissão de Hygiene, 23/fev/1856. Em outra carta confidencial desabafa: "não he a moléstia que me horrorisa, pois que me acho resignado, o que me tem posto atônito he ver o egoísmo desarnado nas pessoas que mais deveriam ajudar ao Governo...", 9/ mar/1856.

${ }_{66}$ Eram poucos os médicos militares. Ao contrario dos engenheiros, que nesse momento se formavam em escolas militares, os médicos eram civis que podiam, eventualmente, se alistar. 
legão em seu favor a liberdade de commercio ${ }^{67 \%}$. Ao mesmo tempo, o Estado era chamado a agir, a intervir. Nos jornais apareciam artigos criticando o presidente por não ter pago o que os médicos pediam.

Em 1855 e 1856, o cólera e a febre amarela eram o único assunto da correspondência entre os presidentes de Alagoas e de Pernambuco e o ministério do Império. Um dos médicos envolvidos nessa terrível guerra foi o Dr. Thomaz do Bom-fim Espindola ${ }^{68}$. Alagoano, recém formado na Bahia foi contratado pelo Presidente da Província para acudir na epidemia de cólera e depois de febre amarela no interior. Possuía formação sólida - em abril de 1858, presta contas do tratamento da febre amarela em relatórios bem escritos; preocupa-se em fundamentar todos os argumentos citando referências e comparando métodos de cura da febre amarela:

"Nesta epidemia, porem, entendi que devia seguir o methodo hespanhol com as modificações que me ião sendo ministradas pela observação à cabeceira do doente, visto como é sabido que as constituições epidêmicas varião segundo os tempos e os lugares. (...) de preferência a infusão de jaborandi, de parreira e casca de laranja com uma colher de aguardente (...) os pós de Dosser, depois de ter obtido transpiração abundante óleo de rícino em infusão de hortelã (...) infusão de canella nas mulheres menstruadas (...) Entendo que os médicos francezes tem muita razão em prescrever os vesicatórios nessa febre, mas entendo também que no nosso clima não ha muita razão para isso; e comigo pensão a este respeito muitos práticos do nosso paiz. (...) Alem do tratamento alopático empregava o homeopathico (...) Não receio de ser taxado de inconsequente por ter adaptado systemas que se dizem antagônicos (...) Hufeland: "L'homeopathie, malgré lês pretentions quelle affiche, fornit la meilleure preuve de la haute puissance de la nature..." ${ }^{\prime 69}$

67 ANRJ, IJJ (9) 255, “a moléstia não deve ser exclusivamente curada pelo Governo, mas por todos que tiverem humanidade" 14 de fevereiro de 1856.

68 Nascido em setembro de 1832, apresentou dissertação ao se formar em 1853 com o sugestivo titulo: A influência progressiva da civilização sobre o homem, 45pgs. Foi deputado pelo partido liberal nas legislaturas de 1878 a 1885. Era sócio do Instituto Archeologico Alagoano, oficial da Ordem da Rosa. 69 ANRJ, IJJ (9) 285, Ministério do Império, Alagoas, correspondência, fl.144, 21/junho/1858. 
O grande desafio era conhecer as realidades locais, sem abrir mão da ciência consolidada. Antes de acudir a febre amarela, Dr. Espindola tinha obtido sucesso com o cólera na Vila do Pilar, dessa experiência publicou um livro sobre o seu método de tratamento. Este jovem de 26 anos andando pelo interior de Alagoas escrevia no meio dos relatórios trechos em francês, ao mesmo tempo que receitava remédios a base de Jaborandi (combinados com outros medicamentos).

O médico que passou boa parte de sua trajetória pelo interior de Alagoas era ilustrado, dedicado ao estudo e comprometido com a cultura do país. Thomaz Espíndola além de médico dedicou-se ao estudo e ao ensino da geografia. Atuou também como jornalista e participou da vida política. Escreveu o compêndio de geografia, Elementos de geografia e cosmografia oferecidas à mocidade alagoana, além do Geographia Alagoana, descrição physica, política e histórica da província das Alagoas, e outros estudos. Foi diretor do Liceu Alagoano, professor de geografia, cronologia e história, assim como Inspetor geral da instrução pública na província $^{70}$. Fez parte da Comissão de 1858 encarregada de formular propostas para enfrentar a carestia.

Problemas crônicos das províncias de Alagoas e de Pernambuco como a seca e a carestia foram tema de muitos ofícios e planos de intervenção elaborados pelo Governo. O Ministro do Império em 1853 ordenou aos presidentes das duas províncias que elaborassem um diagnóstico para poderem fazer um plano de ação. Essa ordem desencadeou a articulação de diversos agentes locais. Os presidentes de ambas as províncias encaminharam listas de perguntas às câmaras municipais, essas prepararam respostas (algumas muito minuciosas ${ }^{71}$ ).

70 Militou pela criação de leis que dessem garantias aos alunos contra o abuso da autoridade dos mestres, pedia o fim do "caráter disciplinar das aulas". Era contra a vitaliciedade do cargo de diretor de ensino, defendia o concurso para as cadeiras do Liceu. Para a escrita de seus livros, usou de relatórios escritos por engenheiros que acabavam de ser publicados, como o de Halfeld, de 1858. Já em 1860, esse mapeamento recém produzido estava nos livros didáticos, nas escolas.

71 A Câmara de Maceió pediu pela compra de uma máquina de ralar mandioca, para otimizar a produção, "conforme no Auxiliador Nacional n.8 de fevereiro de 1855, pág. 282“. Note-se a circulação de periódicos, tratava-se de revista publicada mensalmente pela Sociedade Auxiliadora 
De posse desses diagnósticos, uma comissão nomeada pelo Presidente elaborou um exaustivo relatório final com uma síntese das respostas locais e uma proposta de resolução do problema ${ }^{72}$. Procedimento similar se repetiu em 1858 - foi nesse ano que Thomaz Espíndola participou ${ }^{73}$.

O grande dilema enfrentado por esses homens era receitar remédios que não ferissem o "princípio da liberdade de commercio, tão recomendado pelos mestres da sciencia ecconomica", por isso diziam que era "inviável taxar os escravos, brecando o tráfico interno", ou obrigar pequenos agricultores a plantar alimentos ao invés do açúcar, que estava em alta ${ }^{74}$. O problema dos dois principais gêneros, a farinha e a carne, também não era simples, já tinham tentado concentrar a venda no Mercado Municipal ${ }^{75}$, mas não avaliavam como tão positivos

da Industria Nacional, no Rio de Janeiro, de 1833 a 1892. Outra Camara (cidade ilegível) afirma que o problema era "não temos leis obrigatórias contra esses que se intitulão de vida marítima, a fim de que quotidianamente se entreguem em sua profissão" - assim pelo menos haveria peixe suficiente. (fl.56).

72 A comissão foi nomeada em 1853 em Pernambuco "para conhecimento dos meios convenientes à remoção das causas que produzem a seca”, ANRJ, IJJ 254, Ministério do Império, Pernambuco, 1853-55, fl.64 e seguintes.

73 O Presidente de Alagoas Ângelo Thomaz do Amaral declarou em janeiro de 1858 que "a classe pobre vive com grandes difficuldades. A indiferença da autoridade em uma tal situação, tenho-a por incoveniente no credito do Governo, porquem o povo appela sempre pedindo promptas providencias e por isso tomei as seguintes, que submeto a consideração de VExcia. Nomeei uma comissão de homens intelligentes para investigar se alem das causas geraes, e conhecidas, outras há que sejao peculiares à Província e quais os meios de removê-los". Vai expondo outras medidas, tais como passar três contos para a Camara Municipal prover o Mercado de mais farinha e carne verde...acrescenta: "pode acontecer que nessa operação perca a fazenda publica, mas perderá pouco e em todo o caso para socorrer os miseráveis". ANRJ, IJJ (9) 285, Ministério do Império, Alagoas, fls. 10,11,12. O povo aparece no discurso de algumas autoridades como ator a ser levado em conta pois exercia pressão - assim como no caso do tratamento médico.

74 ANRJ, IJJ (9), 285, Ministério do Império, Alagoas, Relatório final da Comissão, 12 de fevereiro de 1858, fl.77-90.

75 Tinham visões políticas totalmente opostas o presidente de Alagoas e o da Bahia, Cansanção do Sinimbu, nesse momento. A revolta Carne sem osso, farinha sem caroço na Bahia ocorreu, em certa medida, como fruto desse debate, e da expectativa do povo que o governo cumprisse um papel. A Camara Municipal enfrentou o presidente, intitulando-se representante do povo (os vereadores eram eleitos em voto direto, por uma porcentagem alta de pessoas) e decidiu por controlar a venda e o preço da farinha. Sobre a revolta, ver REIS, João José, "Quem manda em 
os resultados. A comissão aconselhava que se favorecesse alguma empresa que quisesse transportar gado de outras províncias que tivessem sobras, "a semelhança do que pratica o Governo Francez". Medida sugerida como viável era investir nas estradas, para incentivar mais produtores, diminuir os destacamentos da Guarda Nacional, para não tirar braços da terra, organizar o crédito territorial da província (para livrar os menos favorecidos da usura de pesados juros), e a principal estrela da proposta: investir na colonização, incentivar o "amor ao trabalho" - a escassez de mão de obra era vista como uma das causas da carestia. Restrições deviam sofrer os africanos livres, considerados os atravessadores dos alimentos, eles deveriam ser empregados no serviço da lavoura, "por meio da colonização voluntária"76.

A comissão alagoana ainda titubeou, experimentou uma inquietação em aderir apenas às leis do mercado, e recomendou medidas combinatórias como o crédito territorial, a diminuição do recrutamento. A pernambucana, por outro lado, foi totalmente taxativa: "bem barata é a carne em São Petesburgo, bem cara em Paris, e mais ainda em Londres. Invejao porem os franceses e ingleses a situação econômica e industrial da Rússia, ou em geral a civilização moscovita?" Mais adiante concluíam:"a lei reguladora dos preços dos differentes productos em todos os tempos e lugares, é a lei da oferta e da procura. É com effeito uma das mais seguras aquisições da economia política conclue Bastiat"77. A idéia era que tratava-se do preço do progresso, era inevitável.

Esses homens debatiam as funções que cabiam ao Estado, o papel que deveria ter, como deveria agir. O presidente da província de Pernambuco não consultou apenas a Comissão, antes disso enviou todos os documentos para obter um parecer de um consultor diferenciado:

Salvador? Governo local e conflito social na greve de 1857 e no protesto de 1858 na Bahia", In DANTAS, Monica D., (org.) Revoltas...., São Paulo, Alameda, 201 1, p.429-448.

76 ANRJ, IJJ (9), 285, Ministério do Império, Alagoas, Relatório da Comissão, 12/fev/ 1858, fl.77-90. 77 ANRJ, IJJ(9), 256, Pernambuco, Ministro do Império, 1858. 
José Ignácio de Abreu e Lima ${ }^{78}$. Para Abreu e Lima, os principais problemas eram o crescimento da grande propriedade e o excessivo recrutamento (tanto para o Exército quanto para a Guarda Nacional) que afastavam os homens do solo: "não tem ubi certo, nem se estabelece nunca, procurando um asylo que nunca encontra". Diz que não há falta de braços, pois se houvesse não teria crescido a grande propriedade, que é movida pelo trabalho braçal ${ }^{79}$. O problema era "o elevado preço dos gêneros coloniais", levando maior pressão à pequena propriedade e impossibilitando a sua sobrevivência. Também falava das grandes obras do pais, das ferrovias e das estradas absorvendo "imensidade de braços", tirando-os do plantio. Abreu e Lima atribuía a situação da carestia ao preço do progresso, só que não estava tão disposto, como seus colegas, a pagar essa conta.

\section{Na barca Pensamento feliz, vão os cocos para os bolinhos do chá}

Outro circuito operante para a prática política no Império era o privado, o das conversas pessoais, ditadas pelas amizades, pelas relações familiares e partidárias. $\mathrm{O}$ historiador pode tentar reconstituir através de acervos da correspondência particular de políticos do período. Analisamos parte do rico acervo do Senador Nabuco de Araujo e do Visconde de Olinda, dois dos principais políticos do período, ministros atuantes nos anos 1840 e 1850. Privilegiamos as cartas trocadas com homens em atuação nas províncias que nos interessam na pesqui-

78 O presidente era Benevuto Augusto Magalhães Taques, ficou do final de 1857 até dezembro de 1858. Abreu e Lima era filho de José Inacio de Abreu e Lima, o padre Roma, líder executado pelo envolvimento na revolução de 1817. Saiu do Brasil em 1818, envolvendo-se nas guerras de independência da América espanhola. Foi um dos generais de Simón Bolivar. Esteve nos Estados Unidos, na Europa. Era sócio do IHGB. Em 1843 publicou o Compendio da História do Brasil, dedicado a S.M.I., "em formato pequeno para vulgarizar a sua leitura", e em 1855 publicou O Socialismo, divulgando a ideia de "fazer do gênero humano uma só família", "tornar o homem cidadão do mundo", "é esse um desígnio da Providencia".

79 Ataca de maneira contundente o principal argumento de grande parte das elites, a falta de braços. Era quase uma tópica discursiva, circulando na imprensa, nos discursos parlamentares. 
sa, Pernambuco, Alagoas, Mato Grosso e Minas Gerais. Para fechar esse texto, abordaremos aspectos pontuais dessa documentação.

Francisco Joaquim Gomes Ribeiro era advogado e foi nomeado para um cargo em Alagoas. Prometeu para o Visconde de Olinda no Rio de Janeiro que escreveria assim que lá chegasse, mandando notícias. No dia 24 de fevereiro de 1845 mandou uma longa carta contando em detalhes tudo que vinha ocorrendo, os impasses envolvendo Vicente Ferreira de Paula e o esforço do Lopes Gama para tirá-lo das matas. Ao final da carta, avisou que tinha enviado "200 cocos para os bolinhos do xá" pela barca Pensamento Feliz. ${ }^{80}$ Os nomeados por determinado gabinete para os diversos cargos no país compunham redes de informação política, de viabilização de negócios e também de circulação de produtos locais...

Antonio Coelho de Sá e Albuquerque estava na presidência de Alagoas em 1854, quando escreveu para o amigo Nabuco, Ministro da Justiça. Podemos presumir o grau de intimidade através da assinatura com o apelido, Catoulé. Na carta fala da imprensa local, faz um resumo das principais disputas, fala do governo em Pernambuco, do jornal que estão editando, o União e concorda que "sim, a linguagem deve ser a da moderação”. Depois entra nos negócios:

Amanhã vai ser publicado um interessantíssimo artigo acerca das duas estradas de ferro, da Bahia e Pernambuco. Se fosse possível que elle fosse transcripto nos jornaes dessa Corte, seria muito bom, porque elle convem aos nossos interesses. Rogo-lhe que se encarregue de promover essa transcripção. Á um ministro não é custoza a obtenção de certos favores.

Depois de cuidar dos negócios, explicitando a faceta material da política, termina a carta com uma das tópicas dessa documentação,

${ }^{80}$ Naquele momento, quando uma guerra que duraria o ano inteiro apenas começava e ele dizia que tudo estaria resolvido em dois tempos, o nome não podia ser mais oportuno. IHGB, Coleção Marques de Olinda, Pasta 17, lata 213. Carta de 20 de fevereiro, respondida no dia 24 de março de 1845. Mais tarde, em maio de 1854, Sebastião do Rego Barros quando presidente do Pará enviaria um macaquinho prego "muito manso" para Naninha, a mulher de Nabuco de Araujo. 
tema presente em quase todas as cartas que Nabuco, Visconde de Olinda e Visconde de Uruguai recebiam enquanto eram ministros, o pedido por cargos:

Muito lhe agradeço o bom acolhimento que deu ao meu interesse pela nomeação do Dr. João da Mata Correa Lima. (...) O Mathias espera alguma protecção sua para o filho. Não se pode ser Ministro. Adeus. Meus respeitos à Sua Exma Mulher. Acceite meu abraço do seu colega e mui afectuoso amigo. Catoulé.

Havia uma consciência de que aquele era um ônus quase "natural" que vinha com o posto do ministério, um pedido de desculpas retórico, como quem dissesse: compreendo que estou incomodando, mas você é ministro. Alguns pedidos eram atendidos, outros, todavia, não eram. Na carta do Chefe de Polícia de Pernambuco e aliado políticoJerônimo Martiniano Figueira de Mello, vemos o acento na relação pessoal com o recomendado, "meu compadre", "meu Fernando":

Muito te agradeço o haveres concorrido efficasmente para o despaixo do meo Compadre Jacarandá, que se mostrou mto penhorado por essa tua bondade, e quanto ao meu Fernando espero que não deixarás de despaixalo Juiz de Direito ou pelo menos Juiz dos Orphãos desta cidade (...) Acredita-me Nabuco, será para mim uma verdadeira fellicidade o ver despaixado para a magistratura a esse amigo fiel de minha infância cuja illustração e qualidade são reconhecidas e apreciadas. Não se esqueça nunca dos conselhos que nos prestou no Rio Formozo e do que fez nas Allagoas durante a revolta da Praieira.

Várias credenciais estavam na mesa, a amizade de infância, traduzida em confiança, a ilustração e a aliança durante a batalha, a lealdade na luta passada. Jerônimo M. F. Mello tinha esse histórico com Nabuco, essa conexão forte com a Praieira, quando Figueira de Mello comandou a repressão e Nabuco presidiu a devassa, condenando centenas de rebeldes. Também José Bento da Cunha Figueiredo vinha escrevendo para Nabuco pedindo por Fernando Affonso de Mello, e mostrava-se desapontado com a demora da indicação: 
“(...) he muito inteligente como sabes (...) educar os oito filhos que tem, não he justo que se abandone um aliado que tantos serviços prestou até contra os interesses de parentes seus... já vês que não fallo por espirito de patronato, que não tenho quando se trata do bem publico. Conto pois de certo que me satisfarás". ${ }^{81}$

Indicavam nomes, pedindo um favor, mas era preciso ter algumas prerrogativas, havia necessidade do mérito e da conveniência política. Em outra carta, apelou: "coitado do Fernando!”. Os desentendimentos também apareciam, José Bento ficou muito irritado com uma decisão que o desautorizara e desabafou: "Ora Sr. Nabuco, veja que não sou criança...". ${ }^{82}$

Sebastião do Rego Barros era mais direto e cobrava fidelidade:

diga-me francamente para eu saber dirigir, e terás tu atirado para um canto esses nomes, que eu tanto recomendei, assim como ao Paraná! Meu caro, uma mão lava a outra e ambas o coração. Recomenda-me a Naninha. Tem saúde.

A intimidade dos dois era grande, frequentavam juntos o cassino, Nabuco mandava recado de mulheres nas cartas. Rego Barros estava na presidência do Pará, o que para ele era prova máxima de que era "bom e fiel amigo"; dizia-se um "pobre desterrado" no exílio, "vivendo entre trovões e chuva e tendo visitas do Tuxanas com sua gente". ${ }^{83}$

A correspondência revela incertezas, "he necessário que se não persuadas que tudo he mar de rosas, que tudo está feito: essa paz serena está pregada com cuspo: convem consolidal-a", ${ }^{84}$ um dos modos

${ }^{81}$ IHGB, Col. Sen. Nabuco, DL 363.30, José Bento da Cunha Figueiredo, Carta de 14/nov/1853.

82 IHGB, Col. Sen. Nabuco, DL 363.30, carta de 8/dez/1853 - Nabuco respondeu no dia 22 de dezembro. No dia 31 de dezembro mais desapontado: "fação pois o que quiserem. De que me serve recalcitrar? Também nada mais direi sobre o Fernando, nem sobre o Favilla: faças o que quiseres".

83 IHGB, Coleção Senador Nabuco, Lata 362, Pasta 58, Sebastião do Rego Barros. Carta de $5 /$ dez/1853. É de se notar o modo como se refere às visitas dos líderes indígenas, na carta de 21/ $\mathrm{jan} / 1854$.

${ }^{84}$ IHGB, Col. Sen. Nabuco, 363,31, José Bento da Cunha Figueiredo, 9/julho/1854. 
que estavam usando para trocar o cuspe pelo cimento era o "sistema de destacamentos volantes", ou seja, fazer as tropas de linha cuidarem da polícia pelo interior da província, auxiliando delegados em diligências, auxiliando no recrutamento. Na sequência, oficiais do Exército assumiam delegacias nos locais considerados mais sensíveis. Outra medida era cuidar da Guarda Nacional, José Bento empenhava-se no processo de reordenamento, que incluía desarmar "a população do interior com cautela" e nesse primeiro momento só ir armando a Guarda Nacional "naqueles logares em que hajam chefes de minha confiança". ${ }^{85}$

A correspondência mostra também disputas, discordâncias e alianças consolidadas. O ministro Nabuco de Araujo estava no Rio de Janeiro, preparava a reforma do Judiciário, comunicava-se oficialmente com todos os presidentes das províncias do Império, deputados na Assembleia, senadores, conselheiros, despachava com o Chefe de Polícia, e trocava cartas pessoais semanais com diversos correspondentes em Pernambuco, Paraíba, Alagoas pedindo e recebendo notícias detalhadas da política local e dos negócios. Eram aliados e discutiam também estratégias do partido.

As disputas ficam claras quando falam da política - Nabuco ficou insatisfeito com o resultado das eleições em Pernambuco - mesmo com o governo no poder, mesmo com todo o aparato, não foi a vitória esperada.

Apezar do que por ai mandarão dizer e do que me dizes em tua carta não acho a Elleição provincial má, tem gente nova e muitos dos que seria bom que fossem reeleitos não o forao, mas em tudo isso não vejo senão mais atividade de parte de uns e negligencia de outros ${ }^{86}$

Figueira de Mello observou, propondo um diagnóstico:

Contigo senti o resultado da elleição provincial pelos mesmos motivos (...), mas a causa delle está essencialmente na indisciplina do nosso partido, e obliteração das suas crenças na sua falta de direção. Como sabes a policia não tem uma

85 IHGB, Col. Sen. Nabuco, DL 363,30, José Bento da C. Figueiredo, 14/nov/1853.

86 IHGB, Col. Sen. Nabuco, Lata 366, Pasta 59, Barão de Boa Vista, Trape, 30/dez/1853. 
parte activa, (...) a G. Nacional quasi não tem Chefes conhecidos (...) Em taes circunstancias os nossos amigos políticos do centro, achao-se sem norte, sem direção (...) vão obrando como lhes parece melhor e em favor de quem mais lhe pede os votos. ${ }^{87}$

Na mesma carta observava como sempre escrevia aos amigos "dando-lhes a necessária direção, perdendo assim um tempo precioso aos meos interesses domésticos e aos deveres do meo lugar". Figueira de Mello diferenciava seus papéis no cotidiano: o esforço devido ao partido e à política, os trabalhos domésticos e os deveres do cargo público (mesmo que tivesse já outras tantas vezes indicado sobrinhos, compadres para empregos públicos - não entendia haver incoerência). O problema seria a falta de controle na província, muitos faziam o que queriam, faltava direção aos conservadores.

Tanto José Bento, como Figueira de Mello, Sérgio Teixeira de Macedo e Sebastião do Rego Barros ficaram irritados com a nomeação de alguns nomes da oposição para cargos públicos em Pernambuco, e eram apenas postos menores. Indignou-os a nomeação de Feitosa para lente do Seminário, "dá-lhe huns óculos por onde possa ele milhor enxergar os negócios da pátria, a ver se ele pode entender milhor a Constituição (...) hei de recomendar mais cuidado", aconselhou José Bento. Alguns anos mais tarde, em 1857 Feitosa preocuparia, pois foi eleito deputado pelos praieiros, e "fez um discurso, chorou, abdicou com Rosas e foi bem a sua ovação, vivas, acompanhamento até a casa... eram em numero de 200 (elles diriao 800...), mas o partido da praia não representa mais nada". ${ }^{88}$

Aparece também nessa correspondência a grande preocupação com a imprensa, a consciência da necessidade de ter um jornal do governo em cada província - o União no Recife, circulava três vezes por semana e um dos redatores era o próprio José Bento da Cunha Figueiredo. Além de fundarem o União, também buscaram comprar o

${ }^{87}$ IHGB, Col. Sen. Nabuco, DL 364.56, Figueira de Mello, 9/jan/1854, grifo nosso.

88 IHGB, Col. Sen. Nabuco, Sérgio Teixeira de Macedo, carta de 14/fev/1857. 
silêncio de outros, ao mesmo tempo prenderam tipógrafos, invadiram e quebraram equipamentos, fecharam jornais considerados radicais. ${ }^{89}$ No Rio de Janeiro, Justiniano José da Rocha explicava para Nabuco, seu amigo pessoal e protetor, que colocar "mais artigos no $\mathcal{7}$. do Commercio por mais que se reproduzam, pouco ou nada se consegue pois esses artigos pouco se prestam às exigências da polemica, apenas servem e nisso muito bem, para as exposições gerais de doutrina." ${ }^{\prime \prime 0}$ Artigos de Justiniano eram reproduzidos em jornais do Brasil inteiro.

$\mathrm{O}$ esforço não era pequeno e articulava dimensões variadas. A trajetória de José Bento da Cunha Figueiredo ilustra um pouco esse empenho. Ficou famoso quando negociou a rendição de Pedro Ivo durante a presidência de Alagoas, disputando diretamente com Honório C. Leão. Dedicou-se a apoiar a fundação da colônia militar nas matas, para controlar a região de tantos conflitos. Foi pessoalmente em 1852 até a sede da colônia militar Leopoldina para sua inauguração, atravessando região de dificílimo acesso. Ficou o longo período de seis anos entre as duas províncias, Alagoas e Pernambuco. Formado em direito em Olinda em 1833, já conhecia parte considerável das elites locais. Nesse longo período na administração, esforçou-se para influir nos poderes locais. Quando saiu, veio outro nome do círculo de confiança de Nabuco de Araújo e dos conservadores, Sérgio Teixeira de Macedo.

As províncias de Pernambuco, Alagoas e da Paraíba formavam um bloco regional econômica e politicamente e tiveram presidentes de

\footnotetext{
89 "Em 11 de janeiro de 1849 a polícia de Figueira de Mello confiscou a edição do Diário Novo e espancaram e prenderam os distribuidores. No dia 13, a casa do impressor Santos Caminha foi varejada, dia 25 ele foi preso e recrutado para o exército. A circulação foi suspensa a 1 de fevereiro de 1849”. Mas a Tipografia da viúva Roma continuaria imprimindo folhetos e outros jornais liberais - era o controle dessa produção que Honório buscava e por um período conseguiu. Seria impresso nessa tipografia o radical $A$ revolução de Novembro, que circulou de 19 de agosto de 1850 até dezembro de 1852. Afonso de Albuquerque Melo, primeiro diretor da folha, "do povo contra o poder", denunciou no jornal as violências policiais e as ameaças que faziam constantemente à senhora viúva Roma "para ver se desiste da empresa". Cf SODRÉ, Nelson Werneck, História da Imprensa no Brasil, São Paulo: INTERCOM, Porto Alegre: EDIPUCRS, 2011 (1ª. ed. 1966).p.223, 235. ${ }^{90}$ IHGB, Col. Sen. Nabuco, DL 365.42, Justiniano José da Rocha, Carta sem data, talvez jan/ 1859.
} 
confiança do gabinete - em 1851 para a Paraíba foi o Catoulé, para Alagoas José Bento, para Pernambuco depois de Honório Carneiro Leão, foi José Ildefonso de Souza Ramos, um dos combativos líderes conservadores (e mais tarde viria o José Bento, de 1854 a 1856) ${ }^{91}$. Havia uma dimensão partidária, para além da simplesmente administrativa - no sentido de uma luta política, da implantação de um projeto político. José Bento era direto: "repito o pedido de mais alguma força de linha para poder executar o pensamento do governo". ${ }^{92}$

Ao estudarmos a jurisprudência e a administração, não podemos descurar da disputa de projetos políticos em campo. Aumentar as tropas, circular rebeldes e soldados, nacionalizar o Exército foi um projeto bem sucedido dos conservadores. Manter correspondência ativa com as lideranças provinciais para cuidar do andamento da política local, publicar artigos no jornal defendendo uma pauta, empenhar-se na aplicação de algumas leis e não de outras foram formas de atuação colocadas em prática.

A dimensão privada, dos pedidos por cargos, da recomendação para publicar um artigo favorável aos negócios, não esteve ausente do processo de institucionalização da política e do governo no Império. Mas uma não exclui a outra. Não podemos, ao reconhecer que havia uma lógica dos favores (aliás nada simples) desprezar a vida institucional. Andavam juntas, articulavam-se e formaram desenhos diversos pois eram variadas as disputas materiais e políticas em campo. Reduzir a vida política do Império ao clientelismo não ajuda a esclarecer, ao mesmo tempo pensar a vida institucional abstratamente (tendência de certa forma dominante atualmente), distante da atuação política e da

${ }^{91}$ Para um estudo da política dos conservadores, ver NEEDELL, Jeffrey, The Party of Order: the conservatives, the state and slavery in the Brazilian monarchy, 1831-1871, Stanford Univ. Press, 2006. Trabalhos mais recentes vem procurando ressaltar e tematizar a dimensão do conflito na década de 1850 , FERRAZ, Paula Ribeiro, O gabinete da conciliação: atores, ideias e discursos (1848-1857), Dissertação de mestrado, História, UFJF, 2013; ESTEFANES, Bruno F., Conciliar o Imperio, o marquês de Paraná e a política imperial, 1842-1856, São Paulo, AnnaBlume, 2013.

${ }_{92}$ IHGB, Col. Sen. Nabuco, DL 363.30, José Bento da C. Figueiredo, 14/nov/1853. 
vida material dos homens no seu tempo também ilumina uma dimensão bastante parcial da construção do Estado.

\section{Bibliografia}

GARVALHO,J. M., Teatro de sombras: a política imperial, Rio de Janeiro, Iuperj/ Vértice, 1988.

DOLHNIKOFF, Miriam, O pacto imperial, origens do federalismo no Brasil, S. Paulo, Globo, 2005.

ESTEFANES, Bruno F., Conciliar o Imperio, o marquês de Paraná e a política imperial, 1842-1856, São Paulo, AnnaBlume, 2013.

FERRAZ, Paula Ribeiro, O gabinete da conciliação: atores, ideias e discursos (18481857), Dissertação de mestrado, História, UFJF, 2013.

GARNER, Lydia M. N. In Pursuit of Order: a study in Brazilian centralization, the Section of Empire of the Council of State, 142-1889. Tese de doutoramento: The Johns Hopkins University, 1988.

LOPES, J. Reinaldo, O Oráculo de Delfos: o Conselho de Estado no Brasil Império, São Paulo, Saraiva, 2010.

MACHADO, André "As interpretações dos contemporâneos sobre as causas da cabanagem e o papel do parlamento", Revista de História, São Paulo, n.175, jul-dez 2016.

MARTINS, Maria Fernanda Vieira, A Velha arte de governar, um estudo sobre politica e elites a partir do Conselho de Estado, 1842-1889, Rio de Janeiro, Arquivo Nacional, 2007.

MAMIGONIAN, Beatriz G., Africanos livres, a abolição do tráfico de escravos no Brasil, São Paulo, Cia das Letras, 2017.

MOTTA, Márcia. Nas fronteiras do poder, conflitos de terras e direito agrário no Brasil de meados do século XIX, Rio de janeiro, Vicio de Leitura, Arquivo Publico do Estado do RJ, 1998.

NEEDELL, Jeffrey, The Party of Order: the conservatives, the state and slavery in the Brazilian monarchy, 1831-1871, Stanford Univ. Press, 2006.

OLIVEIRA, Maria Luiza Ferreira de, "Resistência popular contra o Decreto 798 ou a "lei do cativeiro": Pernambuco, Paraíba, Alagoas, Sergipe, Ceará, 1851-1852", In DANTAS, Monica D. (org.) Revoltas, motins, revoluções, 
homens livres pobres e libertos no Brasil do século XIX, São Paulo, Alameda, 2011.

OLIVEIRA, Maria Luiza F., "As guerras nas matas do Jacuípe”, In Revista de Pesquisa Histórica CLIO, Recife, UFPE, n.33.2, 2015.

OLIVEIRA, Maria Luiza F., "O Exército e a 'dificil luta contra a independência dos homens do campo': embates na construção do Estado no Brasil, 1840-1870", In SOUZA, Adriana Barreto de et alli, Pacificar o Brasil, das Guerras fustas às UPPs, São Paulo, Alameda, 2017.

PARRON, T., A politica da Escravidão no Império do Brasil, R. Janeiro, Nova Fronteira, 2011.

QUINTAS, Amaro, “O Nordeste, 1825-1850”, In Sérgio Buarque de Holanda (org.) O Brasil Monárquico, Dispersão e unidade, HGCB, T.II, $2^{\circ}$.vol., São Paulo, DIFEL, 1964.

RIBEIRO, José Iran, O Império e as revoltas, Estado e nação nas trajetórias dos militares do Exército imperial no contexto da Guerra dos Farrapos, R. Janeiro, M. da Cultura, Arq Nacional, 2013.

REIS, JoãoJosé, "Quem manda em Salvador? Governo local e conflito social na greve de 1857 e no protesto de 1858 na Bahia", In DANTAS, Monica D., (org.) Revoltas...., São Paulo, Alameda, 2011.

SILVA, Edson Hely, O lugar do indio, conflitos, esbulhos de terras e resistência indígena no século XIX: o caso de Escada-PE (1860-1880), Dissertação de mestrado, História, UFPE, Recife, 1995.

SOUZA, Adriana Barreto de, OExército na consolidação do Império, umestudo histórico sobre a política militar conservadora, Rio de Janeiro, Arquivo Nacional, 1999.

SODRÉ, Nelson Werneck, História da Imprensa no Brasil, São Paulo: INTERCOM, Porto Alegre: EDIPUCRS, 2011 (1ª . ed. 1966).

VELLASCO, Ivan, As seduções da ordem, violência, criminalidade e administração da justice, Minas Gerais, século 19, Bauru, EDUSC, São Paulo, ANPOCS, 2004.

Recebido: 24/10/2017 - Aprovado: 01/02/2018 